\title{
管路慣性を応用したマイクロポンプの最適構造*
}

\author{
吉田和 弘*1, 鄭 淵 午*2, 瀬戸 毅*3 \\ 高城邦彦*4, 朴重 濠*1, 横田畺一*1
}

\section{Optimal Structure of a Micropump Using Inertia Effect of Pipeline Element}

Kazuhiro YOSHIDA*5, Yeon-Oh JUNG, Takeshi SETO, Kunihiko TAKAGI, Jung-Ho PARK and Shinichi YOKOTA

\footnotetext{
${ }^{* 5}$ Precision and Intelligence Loboratory, Tokyo Institute of Technology,

R2-41, 4259 Nagatsuta-cho, Midori-ku, Yokohama-shi, Kanagawa, 2268503 Japan
}

\begin{abstract}
For fluid microactuators and microfactory, the authors have proposed a novel high output micropump using inertia effect of pipeline element which has a pipeline element in place of an outlet check valve and verified the effectiveness with a fabricated micropump. To increase the output power and to miniaturize the size, this paper establishes a simple nonlinear mathematical model with lumped parameters and verifies the effectiveness comparing the simulation results with the experimental results. Then, the optimal structure of the micropump is investigated through the simulation with different sizes of the pipeline element and so on. Lastly, a micropump is fabricated and the load characteristics are experimentally investigated.
\end{abstract}

Key Words: Micromachine, Micropump, Optimum Design, Modelling, Actuator, Mechatronics and Robotics, Piezo-Element, Fluid Power Systems

\section{1. 緒言}

半導体加工技術の発展にともない, 産業用プラントの 内径 $10 \mathrm{~mm}$ 程度の配管系統のメンテナンスシステム, マイクロファクトリ, 個別に流体パワー源を持つ小形流 体アクチュエータなどに応用するためのマイクロマシ ンの研究が進められている( ${ }^{(1)(3)}$. たとえば, 配管系統の メンテナンスをおこなう管内作業マイクロマシンにお いて, 垂直上昇, 長距離移動およびメンテナンス作業な どを行うためには, 高パワーが必要とされる. そこで, 著者らの一部は出力密度が高い流体パワーに着目し, 簡 単化した理論解析により, 大きさ $10 \mu \mathrm{m}$ 立方から $10 \mathrm{~mm}$ 立方の範囲において流体アクチュエータが出カエネル ギー密度において他のアクチュエータに比べ高いこと を確認し ${ }^{(4)}$, 流体駆動形マイクロマシンの開発を進めて いる(4)(7).

流体駆動形マイクロマシンを実現するためには, 流体 パワー源となるマイクロポンプが必要である. 特に, 管 内作業マイクロマシンの場合, マイクロアクチュエータ

* 原稿受付 2003 年 12 月 16 日.

*1 正員. 東京工業大学精密工学研究所 ( $-226-8503$ 横浜市緑 区長津田町 4259).

*2 正員, 東京工業大学大学院.

*3 正員, セイコーエプソン(株) (垔393-8502 諏訪市大和 3-35)

*4 セイコーエプソン(株).

E-mail : yoshida@ pi.titech.ac.jp
に効率よく流体パワーを供給するために, 搭載可能なサ イズで高パワーを有するマイクロポンプが必要である. これまで $\mu$ TAS（Micro Total Analysis Systems）のため,

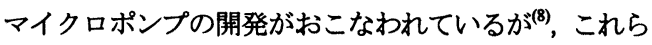
は流体の正確な搬送を目的としたものであり，流体パワ 一源のための研究は著者らの研究以外はほとんどおこ なわれていない.

発生力および応答性が高い積層形圧電素子は，高出力, 小形の流量パワー源を実現するアクチュエータの有力 な候補のひとつである. しかし, 変位が小さいため出力 の限界があると考えられる.そこで著者らの一部は共振 現象を用い, 変位を桩大することで高出力を図った体積 $1 \mathrm{~cm}^{3}$ の圧電マイクロポンプを開発している( ${ }^{(6)}$. また, 従 来のダイアフラム式ポンプの吐出チェック弁の代わり に管路要素を設け，管路慣性を応用した体積 $2.3 \mathrm{~cm}^{3}$ の 新構造の高出力圧電マイクロポンプを開発し, 実験的な 検討に基づきその有效性を実証している ${ }^{(3)}$. しかし, 試 作ポンプの各寸法は，まだ十分には検討されていない. パワーを要する作業をおこなう流体駆動形マイクロマ シンを実現するためには, さらなる高出力化および小形 化が望まれる.

本報では，管路慣性を応用したマイクロポンプの高出 力化および小形化を図るため, 最適構造について検討す る. まず, 本マイクロポンプの简単化した非線形集中定 数系の数学モデルを構築し, 実験結果との比較により, 
その有効性を検討する.つぎに, 得られた数学モデルを 用い, 各部の寸法を変化させてシミュレーションをおこ ない最適構造について検討する. 最後に, マイクロポン プを試作し, 特性実験をおこない最適構造の有効性を確 認する。

\section{2. 管路慣性を応用したマイクロポンプ}

$2 \cdot 1$ 動作原理 著者らの一部が提案し, 試作した 管路慣性を応用したマイクロポンプを図1に示す. サイ ズ3.5 × $3.5 \times 9 \mathrm{~mm}^{3}$ の積層形圧電素子PZTを駆動源とし て用い, 従来のダイアフラム式ポンプの吐出チェック弁 の代わりに設けた管路要素（直径 $\phi 0.75 \mathrm{~mm}$, 長さ $6 \mathrm{~mm}$ および直径 $\phi 1 \mathrm{~mm}$ ，長さ $11 \mathrm{~mm} ）$ 管路慣性を応用する ことで高出力化を実現する構造である ${ }^{(3)}$.

積層形圧電素子を正弦波電圧で駆動し, ポンプ室を圧 縮する吐出行程では, 吸入チェック弁が閉じ, ポンプ室 の内圧は上昇する. このとき, 流体は管路要素を通じて 高速に吐出される. 吸入行程では, 圧電素子の収縮によ り, ポンプ室の内圧が減少するとともに液柱分離が生じ 一定時間流体は吐出側に流出を継続する。

以上のように, 吸入行程および吐出行程ともに吐出す る構造により, 高出力化が可能である.

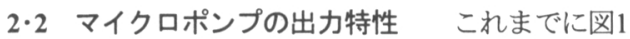
の体積 $2.3 \mathrm{~cm}^{3}$ のマイクロポンプを試作している. ただし， ポンプの下流端の境界条件が一定圧力であることを想 定してあり, 圧力変動を十分低減するため, チェック弁 の上部には樹脂膜によるバッファを設けている，特性

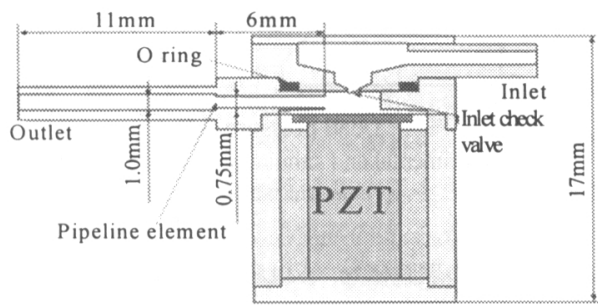

Fig. 1 Schematic of the proposed micropump

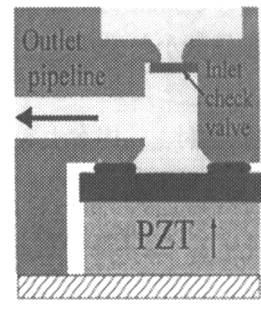

(a) Pumping mode

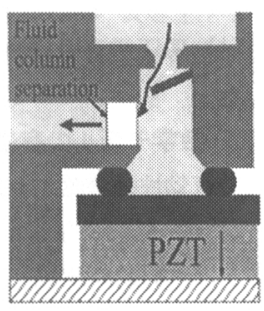

(b) Suction mode
Fig. 2 Working principle of the proposed micropump
実験の結果, 排除体積から計算される以上の流量が得ら れること,および後述する図5に示すようにポンプ室内 圧において 2 種類のモードを有する特性が得られること が確認され, 駆動周波数 $3 \mathrm{kHz}$, 負荷圧力 $400 \mathrm{kPa}$ のとき, 最大出力パワー0.21Wが得られている. なお, 吐出側に 接続した柔軟な樹脂チューブが, 下流端の境界条件が一 定圧力となるようにアキュムレータの機能をはたすこ とも確認されている.

\section{3. 管路慣性を応用したマイクロポンプの 数学モデル}

$3 \cdot 1$ 非線形集中定数系数学モデルの提案 管路慣性 を応用したマイクロポンプの最適設計について検討す るため, 図3に示す非線形集中定数系数学モデルを提案

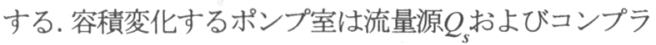
イアンスCでモデル化している. 積層形圧電素子（変位 振幅4.6 $\mu \mathrm{m}$ (100V印加時) ) によるポンプ室の体積変化 $\Delta V_{c}$ による流量は, 駆動角周波数 $\omega$ に対し $Q_{\mathrm{s}}=\left(\Delta V_{c}\right.$ $\omega / 2) \cos \omega t$ である，吸入チェック弁は時間遅れがなく 動作すると仮定し, ダイオードによりモデル化しており， 吸入チェック弁からの流量 $Q_{d}$ は吸入側管路のイナータ ンス $L_{2}$ および抵抗 $R_{2}$ と吸入チェック弁開時の流動抵抗 $R_{3}$ （実測值 $123 \mathrm{kPa} \cdot \mathrm{s} / \mathrm{cm}^{3}$ ) を通じて流入する. 吐出管 路要素はイナータンス $L_{1}$ および流動量抵抗 $R_{1}$ の直列回 路で表す. 吐出管路要素に接続した柔軟な樹脂チューブ がアキュムレータの機能をはたすため, 負荷圧力 $P_{L}$ は一 定圧力としてモデル化している.

液柱分離現象はキャビティモデルによりモデル化し ている. 実際のポンプでは以下のように液柱分離が生じ ていると考えられる. ポンプ室の膨張および管路慣性に よる作動流体の吐出の継続によりポンプ室内圧が低下 し, 絶対圧力0以下になろうとすると液柱分離が発生し, ポンプ室内圧は絶対圧力0に保たれる. また，ポンプ室 の収縮および吸入チェック弁からの流入により作動流

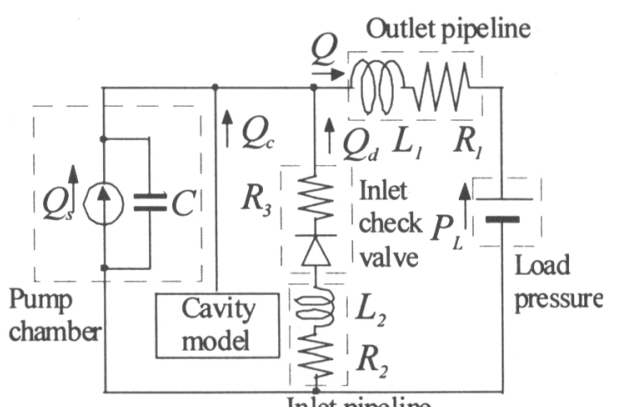

Inlet pipeline

Fig. 3 Proposed mathematical model of the micropump 


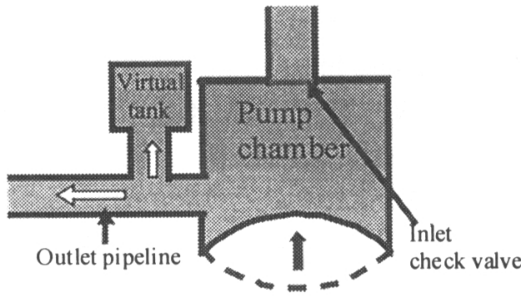

(a) Pumping mode

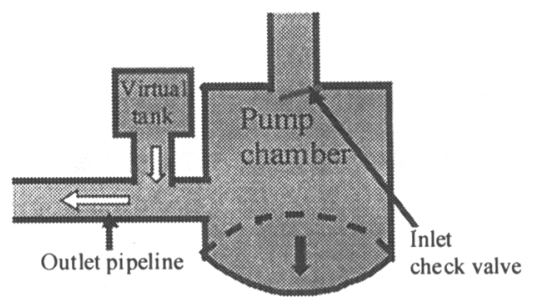

(b) Suction mode

Fig.4 Cavity model

体が供給されると, まず前述の液柱分離により生じた空 洞が小さくなるのに使用され, 空洞がなくなった後ポン プ室内圧が上昇する. 空洞がなくなるまでの間はポンプ 室内圧は絶対圧力0に保たれるというものである. そこ で提案するキャビティモデルでは図4に示すように仮想 タンクを設置し, 吸入行程においてポンプ室内圧が絶対 圧力0以下となろうとしたとき，仮想タンクから絶対圧 力0を保持するように作動流体を供給する（流量 $Q_{c}$ ).

このとき, 供給した作動流体の体積（空洞の体積に相当 する）を流量 $Q_{c}$ を積分して求めておく. 続く吐出行程で は，仮想タンクから供給された作動流体の体積が0とな るまではポンプ室内圧を絶対圧力0に保ちつつ作動流体 を仮想タンクに戻すというものである.

管路の $R, L$ は層流を仮定し, ポンプ室のCの值は作動 流体の体積弾性係数による弾性と積層形圧電素子の弾 性を考慮し, 以下のよう求めている.

$$
\begin{aligned}
& R=\frac{128 \mu l}{\pi d^{4}}, \\
& L=\frac{\rho l}{S}, \\
& C=\frac{V}{K}, K=\frac{1}{\left(\frac{A^{2}}{V k}+\frac{1}{K_{0}}\right)},
\end{aligned}
$$

ただし, $\mu, \rho, K_{0}$ : 作動流体の粘度, 密度, 体積弾性 係数, $l, d, V, S$ : 管路の長さ, 直径, 体積, 断面積, $A$ : ポンプ室のダイアフラムの面積, $k$ : 積層形圧電素 子のばね定数である.以下のシミュレーションにおいて

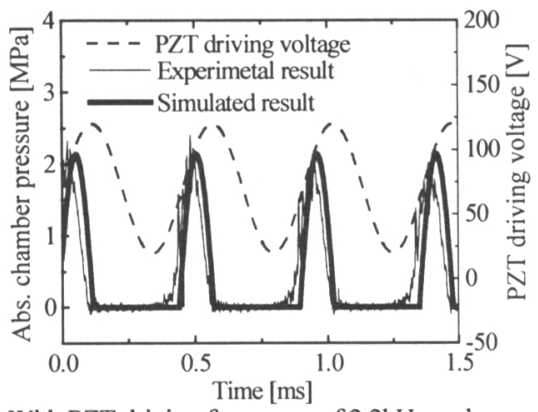

(a) With PZT driving frequency of $2.2 \mathrm{kHz}$ and load pressure of $290 \mathrm{kPa}$

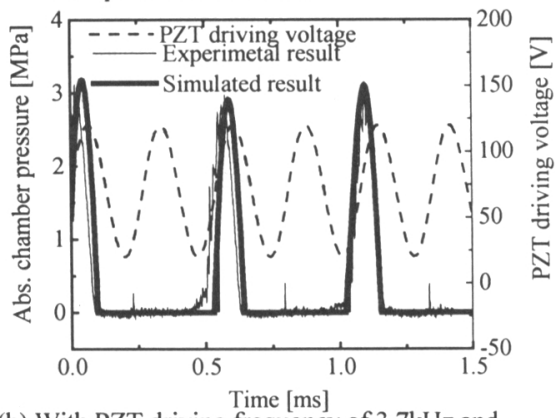

(b) With PZT driving frequency of $3.7 \mathrm{kHz}$ and load pressure of $315 \mathrm{kPa}$

Fig.5 Experimental and simulation results of the pump chamber pressure

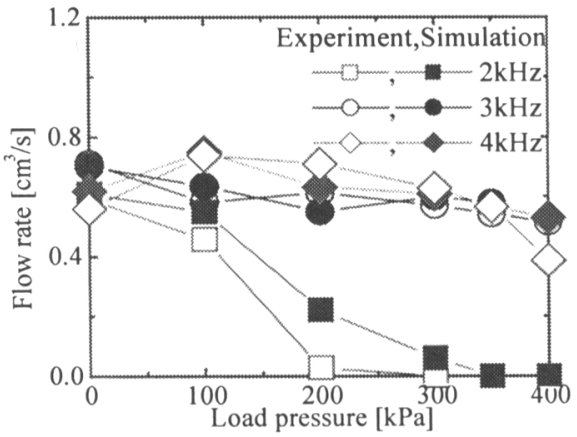

Fig.6 Experimental and simulation results of the load characteristics

は, $R$ は式(1)の理論值を, $L$ は圧力のインパルス芯答の 実測值を参照して式(2)の理論値の 1.3 倍と設定してい る. C はダイアフラムの直径が $6.3 \mathrm{~mm}$ の実測値より求 めた積層形圧電素子の縦弾性係数から式(3)により求め ている.

$3 \cdot 2$ 数学モデルの有効性の検討 提案する数学モ デルの有効性を確認するため, 実験と同一条件でシミュ レーションをおこない，実験結果と比較する．

図 5 に, 駆動周波数 $2.2 \mathrm{kHz}$, 負荷圧力 $290 \mathrm{kPa}$ および 駆動周波数 $3.7 \mathrm{kHz}$, 負荷圧力 $315 \mathrm{kPa}$ の場合においてポ ンプ駆動電圧に対するポンプ室内圧を測定した結果 ${ }^{(3)}$ 
を細い実線で例として示寸. 図 5(a)では積層形圧電素子 の駆動電圧と同一の同期でポンプ室内圧がパルス状に 立ち上がっている.これに対して図 5(b)では, 積層形圧 電素子駆動電圧の 2 倍の周期でポンプ室内圧がパルス 状に立ち上がっている. 本ポンプの特徵である二種類の 圧力モードが生じており, 前者を第 1 モード, 後者を第 2 モ一ドと呼ぶ. 一般に積層形圧電素子駆動圧力の $n$ 倍 の周期でポンプ室内圧が変動する場合で第 $n$ モードと 呼ぶ.

同样の駆動条件において，提案する非線形集中定数 系数学モデルに基づき MATLAB ${ }^{\mathrm{TM}}$ の PowerSystem Blockset を用いてシミュレーションをおこなった結果 を図 5 の黒い実線で示寸.

この結果より, 本数学モデルが本ポンプの特徵である 二つの圧力モードを再現できることおよびポンプ室内 圧の駆動電圧に対する位相およびピーク值がほぼ一致 することが確認された. ただし，実験では生じにくい第 3, 4 モードも条件により生じていた.

図 6 は, 駆動周波数 2 4kHz において負荷圧力を 0 〜 400kPa まで変えておこなった負荷特性のシミュレー ション結果を実験結果と比較した結果である。ただし, 吐出流量は圧力モードが安定した 500 周期分の平均值 により求めている.この結果より, 負荷特性についても 実験結果と傾向が一致することが確認された.

以上の結果より, 提案寸る非線形集中定数系数学モデ ルは, 非常に簡単な構造にもかかわらず有効であること が実験的に確認された.

\section{4. シミュレーションによるポンプ最適構造の 検討}

\section{$4 \cdot 1$ 吐出管路要素の寸法に対する最適構造の検討}

最適構造を検討するために, 前章で得られた数学モデ ルを用い, 同一サイズの積層形圧電素子を用いた場合に おいて, 図 7 に示寸吐出管路要素の直径 $d_{q p}$, 長さ $l$ お よびダイアフラムの直径 $d_{d}$ を変えながらシミュレーシ ヨンをおこなった. 図7に示すように吐出管路要素を一 つの円管とし, 直径を $d_{\phi p}=0.5,0.75,1 \mathrm{~mm}$, 長さを $l=7$,

$12 ， 17,22,25 \mathrm{~mm}$ として負荷圧力を $0 \sim 400 \mathrm{kPa}$ と変え

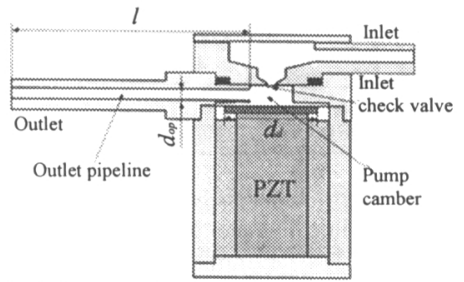

Fig.7 Schematic of the simulated micropump

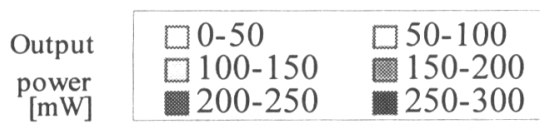

$1: 1^{\text {st }}$ mode, $1,2: 1^{\text {st }}$ or $2^{\text {nd }}$ mode, $2: 2^{\text {nd }}$ mode

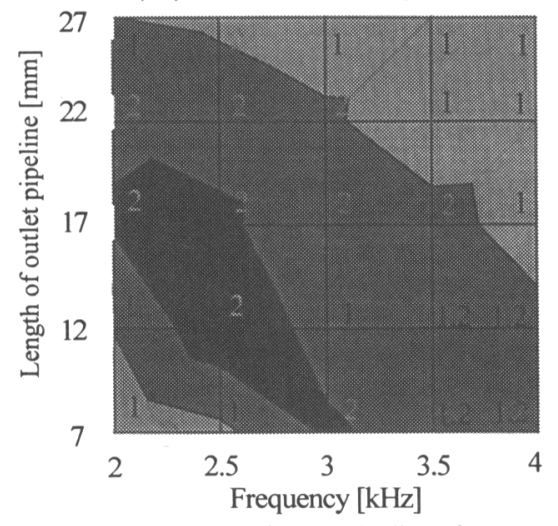

(a) Diameter of outlet pipeline of $0.5 \mathrm{~mm}$

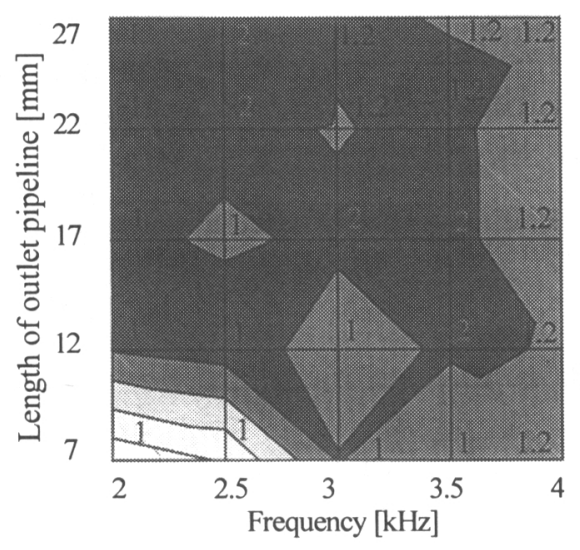

(b) Diameter of outlet pipeline of $0.75 \mathrm{~mm}$

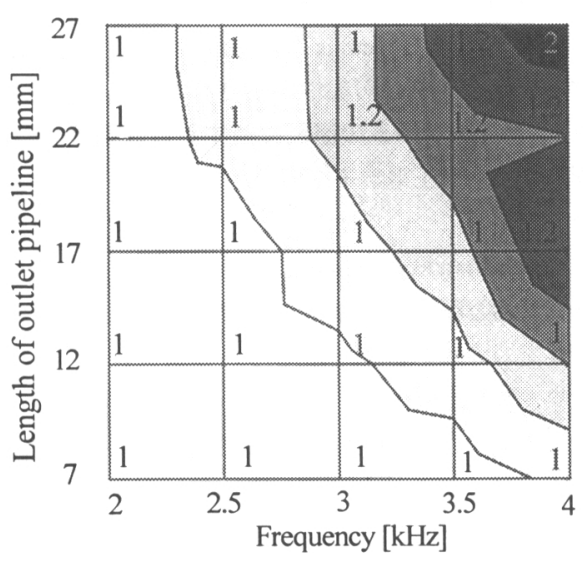

(c) Diameter of outlet pipeline of $1 \mathrm{~mm}$

Fig. 8 Simulated output power with different sizes of the outlet pipeline element and driving frequencies 


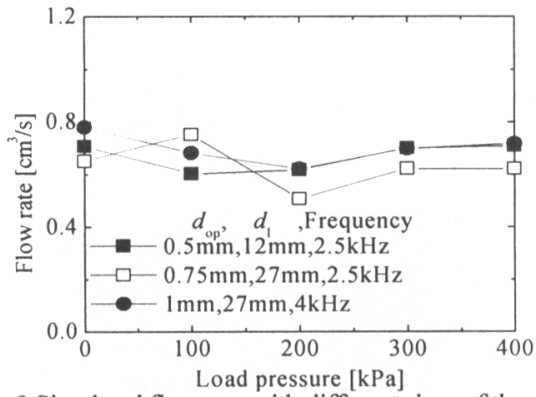

Fig.9 Simulated flow rate with different sizes of the outlet pipeline element and different frequencies

ておこなった. 負荷圧力および駆動周波数の変化範囲は, 実験結果より吸入チェック弁が破損しないと考えられ る範囲に限っている.

ダイアフラムの直径 $d_{d}=6.3 \mathrm{~mm}$ において, 駆動周波数 2〜 4kHz の範囲で負荷圧力に対し最大となった出力パ ワーのシミュレーション結果を図 8 に示す.この結果よ り, 吐出管路要素の直径が小さく, 長さが長い場合では イナータンスが大きくなり, 比較的低い駆動周波数で最 大の出力パワーが生じており, 逆に直径が大きく長さが 短い場合では, 比較的高い周波数で最大の出力パワーが 生じる傾向が確認された. また, 最大の出力パワーが生 じるときは圧力モードが第 2 モードであることから, 高 出力化のためには第 2 モードが必要であることがわか った.

駆動周波数 2 4kHz の範囲で出力パワーが高い条件 を選び, それらの負荷特性を図 9 に示す.この結果より, 本シミュレーションでは吐出管路要素の直径 $d_{i p}=0.5 \mathrm{~mm}$, 長さ $l=12 \mathrm{~mm}$, 駆動周波数 $2.5 \mathrm{kHz}$, 負荷圧 力 $400 \mathrm{kPa}$ のとき, 図 6 の出力パワーが最大となる駆動 周波数 $3 \mathrm{kHz}$, 負荷圧力 $400 \mathrm{kPa}$ のときの実験值よりも $35 \%$ 高い吐出流量 $0.71 \mathrm{~cm}^{3} / \mathrm{s}$ が得られ, ポンプ出力特性の 改善および小形化の可能性が示された.

\section{$4 \cdot 2$ ダイアフラムの直径に対する最適構造の検討}

同一の積層形圧電素子を用いたとき,ダイアフラムの 直径の最適值について検討した. ダイアフラムの直径を $6.3 \mathrm{~mm}$ から $3 \mathrm{~mm}$ および $9 \mathrm{~mm} に$ 変えて同様にシミュレー ションをおこなった, 各ダイアフラムの直径に対し吐出 管路要素の寸法を変え, 出力パワーが最大となったとき の結果を表1に示す.

ダイアフラムの直径が $d_{d}=3 \mathrm{~mm}$ 場合では駆動周波数

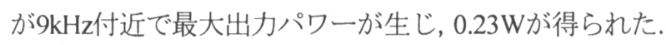
$d_{d}=9 \mathrm{~mm}$ の場合では駆動周波数が $d_{d}=6.3 \mathrm{~mm}$ と同様な值 で最大の出力パワーが得られ, $0.25 W か ゙$ 得られた. また, 現在の寸法であるダイアフラムの直径 $d_{d}=6.3 \mathrm{~mm} に お い$
て出力パワーが最大となった。

以上の結果より, 現在使用している積層形圧電素子に 対しダイアフラム直径 $d_{d}=6.3 \mathrm{~mm}$ が最適值であることが わかった. またダイアフラムを小さくしても出力パワー は大きくは低下しないことがわかり,さらなる小形化の 可能性が確認された. 今後, 積層形圧電素子の寸法を変 えた場合を含め検討する必要がある.

\section{5. 最適構造を有するマイクロポンプの試作}

$5 \cdot 1$ 試作したマイクロポンプシミュレーション結 果に基づき, 最適構造のマイクロポンプを試作した. ダ イアフラムの直径は $d_{d}=6.3 \mathrm{~mm}$, 吐出管路要素の直径は $d_{o p}=0.5,0.75,1 \mathrm{~mm}$, 長さはl=12,17, 22mmである. 試作したポンプの写真を図10に示す.

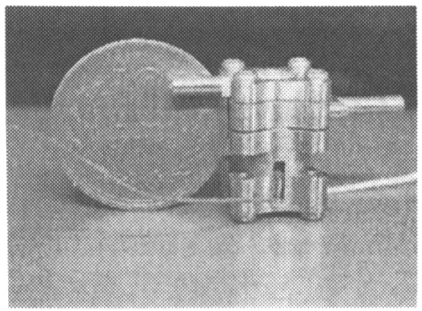

Fig. 10 Photocopy of micropump

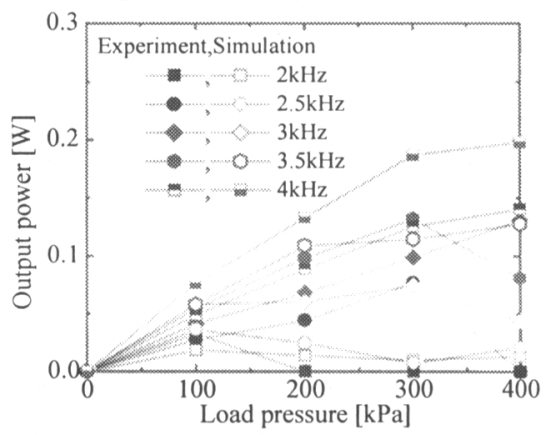

(a) Output pipeline diameter of $1 \mathrm{~mm}$ and length of $17 \mathrm{~mm}$

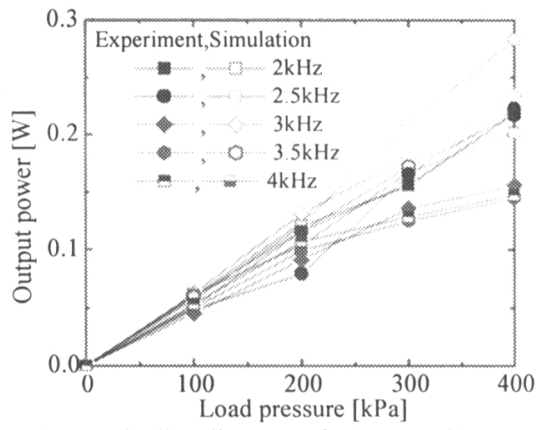

(b) Output pipeline diameter of $0.5 \mathrm{~mm}$ and length of $12 \mathrm{~mm}$

Fig.11 Comparisons of experimental and simulation results 
Table 1 Output power with different sizes of the diaphragm and outlet pipeline

\begin{tabular}{|l|c|c|c|c|c|c|c|c|c|}
\hline Diameter of pump chamber $d_{d}[\mathrm{~mm}]$ & \multicolumn{3}{|c|}{3} & \multicolumn{3}{|c|}{6.3} & \multicolumn{3}{c|}{9} \\
\hline Diameter of outlet pipeline $d_{o p}[\mathrm{~mm}]$ & 0.5 & 0.75 & 1 & 0.5 & 0.75 & 1 & 0.5 & 0.75 & 1 \\
\hline Length of outlet pipeline $l[\mathrm{~mm}]$ & 7 & 12 & 12 & 12 & 22 & 27 & 12 & 12 & 22 \\
\hline Driving frequency $[\mathrm{kHz}]$ & 9 & 8 & 9 & 2.5 & 2.75 & 4 & 3 & 2.5 & 2.5 \\
\hline Output power [W] & 0.22 & 0.23 & 0.22 & 0.28 & 0.29 & 0.29 & 0.21 & 0.25 & 0.22 \\
\hline
\end{tabular}

\section{2 負荷特性实験 作動流体として脱気した純水を} 用い，積層形圧電素子にはオフセット $60 \mathrm{~V}, 100 \mathrm{~V}_{\mathrm{pp}}$ の正 弦波電圧を印加して試作マイクロポンプの特性実験を おこなった.負荷はポンプの下流側に設置した可変絞り により与え,ポンプと可変絞りの間に半導体形圧力セン サ（豊田工機（株），SD220，測定範囲：0〜1MPa）を 取り付けて負荷圧力を測定した. 流量は作動流体の吐出 質量を電子天びんで測定し，10gになるまでの時間を3 回測定し, 平均值を求めている. 負荷圧力およひ駆動周 波数の範囲は前章と同様である.

最大の出力パワーを生じた吐出管路直径 $d_{o p}=0.5 \mathrm{~mm}$ お よび長さ $l=12 \mathrm{~mm}$ の場合, および負荷圧力が高いとき出 カパワーの低下が見られた $d_{q p}=1 \mathrm{~mm}, l=17 \mathrm{~mm}$ 場合に ついて,実験結果をシミュレーション結果と合わせて図 図11に示す.

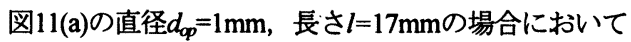
は,出力パワーが負荷圧力をある值より高くなると減少 する傾向が見られた.これはシミュレーション結果と類 似の傾向である. この原因としては, イナータンスが小 さく，図8(c)に示すようにより高い周波数で駆動が適し ているが吸入チェック弁の耐久性のため $4 \mathrm{kHz}$ までに限 定しているためである. 最大の出力パワーは実験とシミ ユレーションで同様に駆動周波数 $4 \mathrm{kHz}$, 負荷圧力 400kPaのとき生じているが, その值には40\%の誤差が生 じている.

図11(b)の直径 $d_{o p}=0.5 \mathrm{~mm}$ ，長さ $l=12 \mathrm{~mm}$ の場合におい ては, 最大出力パワーが生じる条件は実験, シミュレー ションともに駆動周波数 $2.5 \mathrm{kHz}$, 負荷圧力 $400 \mathrm{kPa}$ のき である. 最大パワーの值には $30 \%$ の誤差がある.

以上の結果より, シミュレーションによる出カパワー は絶対值については誤差が大きいが負荷圧力に対する 変化は類似していること,および本ポンプの吐出管路要 素の最適值は直径 $0.5 \mathrm{~mm}$ ，長さ $12 \mathrm{~mm}$ であることが実験
によっても確羿され，提案する数学モデルの有効性の一 部が確認された. 最大出カパワーにおける誤差は, ポン プ室のコンプライアンス值が組立時に変化したことお よびモデル化されていない吸入チェック弁における応 答性および逆流の影響と考えられる.

\section{6. 結言}

本報では,管路慣性を用いたマイクロポンプのさらな る高出力化および小形化のために, 簡単な非線形集中定 数系数学モデルを提案し, 最適構造について検討した. 得られた主な成果は以下のとおりである.

(1)简単な非線形集中定数系数学モデルを提案した.

(2)体積 $2.3 \mathrm{~cm}^{3}$ の試作マイクロポンプの特性実験をおこ ない, 実験結果との比較により, 出力パワー特性の傾 向が類似していることから提案する数学モデルの有 効性の一部が確認した.

(3)提案する数学モデルを用いてシミュレーションをお こない, 最適構造について検討し，その有効性を実験 的に確認した.

\section{文献}

(1)原邦彦, マイクロマシン研究の現状と今後, デンソーテクニカル レビュー, 5-1(2000), 8-14.

(2)特集「マイクロマシン技術一産業技術研究開発制度におけるマ イクロマシンプロジェクト」日本ロボット学会誌,19-3(2002),1-43. (3)T. Seto, K. Takagi, K. Yoshida, J-H. Park, S. Yokota, J. of Robotics and Mechatronics, 5(2003),128-133.

(4)吉田和弘,横田真一,油空と空気圧,25-2 (1994),149-156.

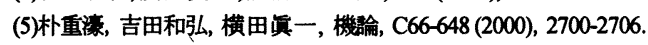
(6)J.-H.Park, K.Yoshida, S. Yokota:Mechatronics, 9-7(1999), 687-702. (7)吉田和弘,郱淵午,横田员一,機論,C69-682 (2003), 1633-1639. (8)D.R. Reyes, D. lossifidis, P.A. Aruoux, A. Manz, Micro total analysis systems, Anal. Chem. 74 (2002) 2623-2628. 